ARTICLE

https://doi.org/10.1057/s41599-019-0246-5

\title{
Decentring antibiotics: UK responses to the diseases of intensive pig production (ca. 1925-65)
}

\author{
Abigail Woods ${ }^{1}$
}

\begin{abstract}
It is widely assumed that the development of antibiotics had a transformative effect on livestock production by making it possible to keep larger numbers of animals in smaller spaces without them succumbing to disease. Using the health and production of UK pigs, ca. 1925-65, as a case study, this article argues that their impact has been overstated. It draws on evidence from veterinary journals, farming magazines, and government-appointed committees to demonstrate the significance of other methods of countering the diseases that emerged in association with intensive production systems. Devised by vets, farmers and other experts, these methods predated antibiotics and evolved alongside them. They were rooted in a shared understanding of pig diseases as highly complex phenomena that resulted from interactions between pig bodies and their environments. Recognition of the roles played by housing, husbandry, nutrition, and pathogens in the production of pig disease suggested multiple possible points of intervention. In situating antibiotics within this landscape of disease prevention and control, this article challenges existing claims about their reception and impact, decentres them from the history of intensive farming, and draws attention to other methods of promoting pig health, which may find renewed applications as we move towards a post-antibiotic era.
\end{abstract}

\footnotetext{
${ }^{1}$ Department of History, King's College London, London, UK. Correspondence and requests for materials should be addressed to A.W. (email: abigail. woods@kcl.ac.uk)
} 


\section{Introduction}

A ntimicrobial resistance (AMR) is currently regarded as one of the greatest threats to human health. Encouraged by the large scale use of antibiotics, it can spread via multiple routes between farm animals, humans and the wider environment (O’Neill, 2016; Woolhouse et al. 2015). Growing recognition of its complexity and prevalence has added urgency to the search for global solutions. However, AMR is not a new problem. First recognised in the 1950s, it has inspired ongoing discussions, scientific investigations, and regulatory proposals. Throughout, high-volume antibiotic use in agriculture has attracted particular attention. It is often claimed that antibiotics made intensive farming possible, creating in the process new threats to human health and animal welfare (Bud, 2007; Kirchhelle, 2018a, 2018b). Antibiotics have been used to promote pig and poultry growth rates, and to prevent and treat diseases that would otherwise run rife on large farms with high stocking densities. Recent regulatory interventions have focussed on restricting their use as growth promoters. Efforts are also underway to reduce their therapeutic and preventive uses, raising questions about how farmers will manage to sustain livestock health, productivity and profit in a less antibiotic-dependent world (WHO, 2015; O’Neill, 2016).

This article aims to inform discussions about post-antibiotic futures, and to unsettle assumptions about antibiotic pasts by examining mid-20th century efforts to tackle pig disease in the UK. The pig industry offers a suitable case for studying antibiotic contributions to livestock health and production because it has a high-health status and is highly intensive. ${ }^{1}$ Currently, around $60 \%$ of UK sows and nearly all fattening pigs are kept indoors, with the average commercial farm containing 500 sows (AHDB Pork). Antibiotics are used widely, although in response to concerns surrounding AMR, consumption halved between 2015 and 2017 (Barton, 2014; Parrot, 2018). Building on previous studies of mid-20th century pig production and veterinary care in the UK (Woods, 2012, 2013), Western Europe and North America (Jones, 2003; Finlay, 2004; Smith-Howard, 2010, 2017; Saraiva, 2016), this account departs from recent analyses of agricultural antibiotics by examining them from the perspective of historically situated concerns with animal health, rather than present-day concerns with human health. It seeks to probe rather than presume the significance of antibiotics to the rise of intensive farming, and to insert farmers' voices into a historical narrative that is currently dominated by scientists and policy makers.
This account is primarily concerned with the therapeutic use of antibiotics to tackle disease rather than as growth promoters used to enhance production. To some extent this is a false dichotomy, for in improving health through the treatment of disease, antibiotics also improved production. Indeed, this was the key motivation for their therapeutic use. To complicate matters further, therapy could blur into prophylaxis, for example when apparently healthy livestock were dosed to prevent them from contracting a disease exhibited by other members of the herd. However, there were (and still are) key distinctions between the preventive/therapeutic uses of antibiotics and their use as growth promoters. The former were employed in higher doses, in response to specific health conditions rather than as low-dose everyday feed supplements. Unlike growth promoters they could only be accessed via vets (Swann et al. 1969). Consequently, the history of therapeutic/preventive antibiotic use can only be understood in relation to pig health and its co-evolution with farming practices and veterinary interventions (Figs. 1 and 2).

In performing the first empirically grounded analysis of these developments, this article will show that throughout the mid-20th century, UK vets and farmers viewed pig disease in profoundly holistic terms, as the product of 'an intricate series of interactions in which environment, nutrition and possible pathogens may all play a part.' (Lamont et al. 1950, p. 737). Multiple routes to treatment and prevention were suggested by this multi-causal disease concept: killing germs with antibiotics was just one of many possibilities. This finding challenges the presumed centrality of antibiotics to the post-war expansion of livestock production and consumption. It also calls into question historians' claims that antibiotic use side-lined hygienic methods and promoted a view of disease as the straightforward product of pathological agents invading susceptible bodies (Anderson, 2004; Bud, 2007). In addition, from a contemporary perspective, it offers some indications for how the sector could maintain pig health in a post-antibiotic world.

The first section documents farmers' initial attempts at 'factory-style' pig production during the inter-war period, over a decade before penicillin became available. It notes the accompanying decline in pig health, the rise of veterinary interest in these animals, and the efforts made by vets and farmers to strengthen pig bodies and reduce their exposure to germs. The outcomes of these efforts reveal that antibiotic therapy was not a precondition for the rise of intensive farming. The second section traces the expansion of indoor pig production in the immediate

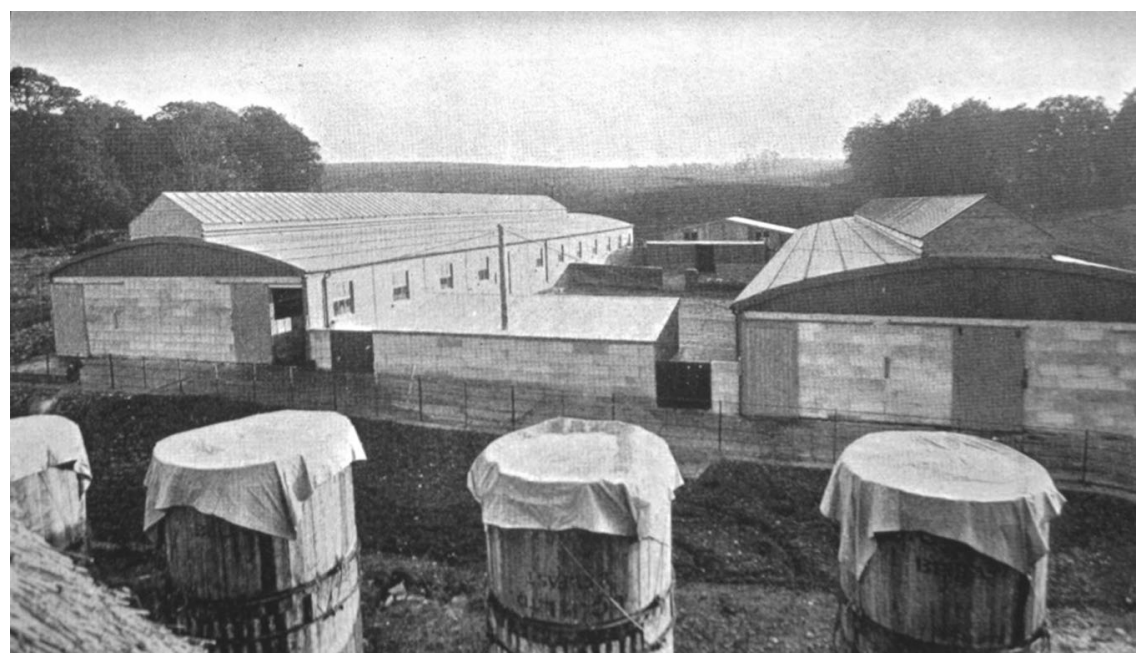

Fig. 1 Piggeries at the Agricultural Research Institute for Northern Ireland (Rae, 1934-5) 


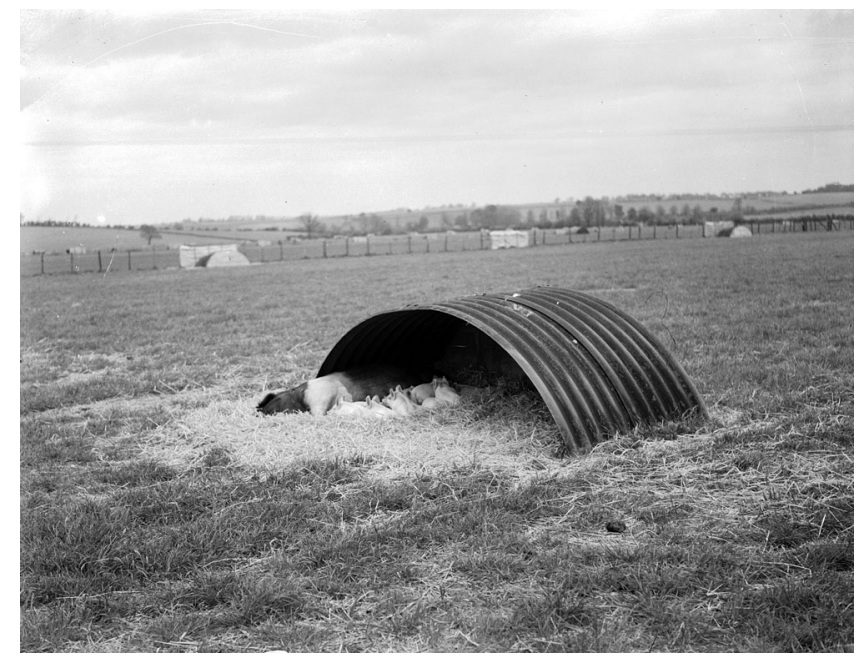

Fig. 2 Pigs and piglets in a field (R. Roadnight, Britwell Salome, 1955). Reproduced by permission of The Museum of English Rural Life, University of Reading, UK

post-WWII decades, and the role played by antibiotics in tackling the health problems which emerged. It shows that antibiotics were ineffective in treating certain diseases and left other infections in their wake. These limitations were widely recognised by pig vets and farmers, and reaffirmed their holistic understandings of disease. Using the disease known as 'Virus Pneumonia of Pigs' (VPP, now Enzootic Pneumonia) as a case study, the final section explores what health interventions these parties elected to use instead of antibiotics. The conclusion reflects on the significance of these findings for historical and contemporary understandings of antibiotic use and livestock production.

This is a largely qualitative analysis. While data exists on the size and structure of pig holdings, there are no statistics on therapeutic antibiotic use in the pig sector. Evidence is drawn from articles and conference reports in the veterinary press, most notably the weekly Veterinary Record, which was received by the majority of the UK veterinary profession, and from reports, editorials, and expert commentary in the farming press. The latter represents 'an unparalleled source for those researching British farmers' (Verdon, 2010, p. 90). Key publications include the popular Farmer and Stockbreeder, and the more specialist Pig Farming magazine, whose audience ranged from mixed farmers keeping pig herds as a side-line, to elite pedigree breeders and specialist factory farmers. The minutes of pig veterinary committees set up by various government-appointed bodies are also an important source of information. Given the limited opportunities for interviews and the impossibility of performing ethnographic observations, these sources provide the best available glimpse of how UK vets and farmers conceived of, and managed pig health in the mid-20th century. While they do tend to privilege elite voices and innovative developments, the views and practices of grass roots vets and farmers can be recovered, for example from the correspondence pages of the veterinary and farming press, and from verbatim accounts of discussions on pig health.

\section{Section 1}

In the aftermath of WWI, UK agriculture sank into a deep economic depression, which stimulated certain pioneering farmers to specialise in the indoor production of pigs. Departing from the common practice of keeping a few pigs as a side-line on mixed farms, they attempted to apply 'the continuous process system used in mass production' (Special correspondent, 1937, p. 789). Pigs were housed for some, if not all of their natural lives, in converted farm buildings or large, purpose-built 'pig palaces' like that owned by the Eccles Provident Co-operative Society, which employed an architect to build a 4000-pig unit near Warrington. These new buildings had concrete floors that removed the need for bedding, and a double row of pens divided by low partitions, with separate, easy-to-clean dunging compartments. Farrowing sows were housed separately in crates, and their piglets removed at weaning. Nourishment was provided by pre-prepared swill, or cereal-based feed that was mixed on the farm or purchased from specialist companies (Farmer and Stockbreeder, 1921; Davidson, 1948).

These practices were inspired by Danish pig farming, which produced consistently high-quality bacon that many British consumers preferred over the home-grown product (Shaw, 1938; Higgins and Mordhorst, 2015). Advocates claimed that pigs produced in this manner were heathier, more comfortable, productive and profitable. Compared with pigs kept outdoors in huts and pens they required less labour, and because they exercised less and slept more, they consumed less feed. Protected from seasonal variations in climate and nutrition, and from diseases such as worms which turned the land 'pig-sick' (Brooks, 1935), they grew at more predictable rates, resulting in relatively uniform carcasses that produced better quality bacon. In addition, it was easier to monitor their health, growth and feed intake, to identify the best breeding stock through the performance of their litters, and to calculate the costs and profitability of production using accounting methods devised by the new field of agricultural economics (Garrad, 1933; Davidson, 1935; Whetham, 1981).

Factory-style production grew more popular in Britain following the 1933 establishment of a Pigs and Bacon Marketing Board. One of several marketing boards created by the state in response to agricultural depression, it aimed to encourage improvements in the quantity, quality, cost-effectiveness and competitiveness of British bacon by creating a stable market. British producers were invited to enter into contracts with bacon factories, which committed them to the regular supply of a set number of pigs of a particular weight and grade. A 'fair' price which reflected the average cost of production was agreed in advance, and producers fined for failing to make their targets. The Board was not particularly successful. Not all producers signed up, and those that did often reneged on their contracts when pork prices exceeded those of bacon. Nevertheless, it generated significant profits for larger, more efficient producers who achieved a regular throughput of pigs (Davidson, 1948; Higgins and Mordhorst, 2015). ${ }^{2}$

Although touted as a healthier means of production, experience soon demonstrated that indoor pigs were extremely prone to disease. According to government veterinary researcher, $\mathrm{WH}$ Andrews (1934), 'all the large breeding establishments get trouble sooner or later.' Much of this 'trouble' was 'not fatal but greatly retards growth and increases the cost of production.' Indoor pigs seemed particularly prone to diarrhoea and coughing, often occurring in conjunction with anaemia (Anthony, 1935; Fishwick, 1935, Lamont, 1938). Losses were especially high in the first six weeks of life. One producer reported that around 30\% of his pigs died before reaching maturity. Many of the survivors failed to thrive, causing costly delays in the fattening of pigs to schedule (McGuckian, 1956). Disease was perpetuated within fattening houses by the continual addition of newly weaned pigs, such that 'in any of the larger pig houses one was greeted by a chorus of coughing...so common that many farmers considered it to be a normal habit among pigs' (Shanks, 1942).

This deterioration in pig health led some producers to seek veterinary aid. Formerly, owing to the low status and low value of 
pigs, they had summoned vets only occasionally, for the treatment of valuable pedigree pigs suffering from disease, injury or farrowing problems (Allen, 1910, pp. 160-161; Agricultural Research Council, 1933a, 1933b), and to conduct preliminary investigations into suspected outbreaks of foot and mouth disease and swine fever, which were notifiable diseases. Swine fever was difficult to diagnose clinically, therefore vets were required to send post-mortem samples to the Ministry of Agriculture's Central Veterinary Laboratory at Weybridge. Its response gave rise to the joke that there were only two pig diseases in existence: 'swine fever' and 'not swine fever' (Anderson, 1961). Emerging health problems demonstrated that this was not the case, however, and provided new opportunities for vets to extend their engagement with pigs.

Early investigations were performed by DJ Anthony, author of the first dedicated veterinary textbook on pig diseases (Anthony, 1940), and holder of the unusual position of veterinary inspector to the leading Staffordshire bacon manufacturer, Marsh and Baxter. He was responsible for overseeing the health of indoor pig units established to supply the bacon factory, and for examining pig carcasses after death to determine their fitness for human consumption. Correlating post-mortem appearances with the signs and symptoms of disease in life, he deduced that visibly sick pigs were just the tip of the iceberg: many of their companions were also sick but did not exhibit symptoms, only reductions in their productive capacity. While unable to pinpoint the microbial causes of disease, he linked the frequency of pneumonia to the bad atmosphere of poorly-ventilated houses. Other 'obscure' conditions he attributed 'either to the food supply or the conditions under which the animals are housed' (Anthony, 1935, p. 75).

Similar conclusions were reached by the veterinary scientists, PL Shanks and HG Lamont, who worked for the Northern Ireland Ministry of Agriculture. In 1926, their aid was sought by Sandy McGuckian, who was an early convert to intensive fattening. His pigs were experiencing high mortality rates which had not improved despite changes in diet and pig breed. McGuckian later reflected that his pigs were suffering from 'a house disease'. Infection of one pig led to the infection of all. Recovery was slow and partial. By 1936, mortality rates were $40-50 \%$, and virtually all of the carcasses inspected showed signs of lung pathology (McGuckian, 1956, p. 25). In light of the 1931 discovery that swine influenza symptoms were caused by a virus and bacteria cooperating to produce a disease more severe than either could cause alone (Shope, 1931), and wider findings on the complex microbial ecologies of infectious disease (Mendelsohn, 1998; Amsterdamska, 2001; Honigsbaum, 2016), Lamont proposed that pig pneumonia infection was caused by influenza virus infection followed by secondary bacterial invasion (Lamont, 1938).

Shanks' investigations revealed the influence of indoor housing conditions on the clinical severity of pig disease. He attributed the finding that up to $100 \%$ of pigs with pneumonia died in winter, but only $10-30 \%$ in temperate conditions, to the large air space, inadequate insulation and draughty windows of many purposebuilt pig houses, whose internal temperatures rose and fell in line with outdoor conditions. In winter, houses were often intensely cold whereas in summer they were hot and humid, their atmospheres laden with evaporation from urine and manure, which condensed on the roof and then dripped back onto the pigs (Shanks, 1942; McGuckian, 1956). In drawing attention to these effects, Shanks challenged the belief that indoor production provided environmental protection to pigs. Lamont and colleagues concluded that 'The pig more than any other farm animal is very much the victim of its environment.' Disease was 'seldom merely the result of the exposure of a susceptible host to a pathogenic organism, but more often it is the summation of an intricate series of interactions in which environment, nutrition and possible pathogens may all play a part' (Lamont et al. 1950, p. 737).

This holistic view of pig disease was reinforced by the work of nutritional scientists. Drawing on the inter-war discovery of vitamins and trace elements in the diet-the so-called 'newer knowledge of nutrition', which was redefining notions of a quality diet (Vernon, 2007) - they confirmed that iron deficiency was the cause of the anaemia suffered by indoor pigs, and that malnutrition in the sow impacted on the health of piglets postweaning. Other mineral and vitamin deficiencies were identified in the manufactured 'artificial rations' fed to indoor pigs (Stewart, 1933; Foot and Kon, 1938-9). According to John Boyd Orr (1935), the major effect of these deficiencies was to undermine disease resistance: the clinical effects of disease depended not only on microbial invasion but also on the food consumed.

The Agricultural Research Council, which was established in 1931 to oversee publicly funded research on agriculture and animal health (Vernon, 1997), sought to advance these various perspectives by appointing three sub-committees on the diseases, husbandry, and nutrition of pigs. In 1933, at the first meeting of the veterinary-dominated pig disease committee, members highlighted the 'disease factors which are accentuated by increasing density of pig populations and increasingly intensive methods of pig rearing' (Agricultural Research Council, 1933a). Recognising that these factors related also to pig feeding and housing, they forged connections with the other two committees (Agricultural Research Council 1938a, 1938b). The survey they commissioned into the causes of pig mortality highlighted the complex microbial ecology of pig disease by identifying multiple pathogens associated with 'scour' (diarrhoea) and pneumonia (Brooksbank, 1937).

Vets and farmers developed various ways of responding to the diseases of indoor production. Although farmers possessed an arsenal of proprietary drugs, which were supplemented from the late 1930 s by the entry of the sulphonamides into veterinary practice (Bowmer, 2018), disease prevention often took precedence over cure. The realisation that diseases had multiple interacting causes encouraged efforts both to reduce exposure to pathogens and strengthen pig bodies so that they could better withstand them. Methods were creative, diverse and wideranging. They reveal that it was possible to manage the diseases of intensive production prior to the discovery of penicillin. Though mortality rates were high, vets and farmers were by no means helpless. As revealed below, the methods they devised continued to evolve and find new applications in spite of the appearance of antibiotics, indicating that the importance of these drugs in advancing indoor pig health and production has been routinely overstated.

One popular recommendation was to move pigs outdoors into partially covered outdoor yards or cheap, moveable huts stationed on pasture, woodland or arable land after harvest. Far from a retrograde step, this represented an alternative vision of agricultural modernity which won considerable support during the interwar years. Proponents argued that it helped to prevent anaemia, cure diarrhoea and reduce coughing (Fishwick, 1935, Woods, 2012). One producer observed, 'you will not kill the pigs nearly so easily by exposure as by cooping them up in a dry, badly ventilated barn' (Forman, 1937, p. 113). Anthony (1935, p. 76) agreed that 'as a preventive measure, nothing beats a permanent grass run for the sow and litter.' Alternatively, indoor housing and husbandry could be adapted to promote pig health. Offering soil, greenstuffs, or iron supplements to young pigs, or painting the sow's teats with dilute ferrous sulphate, helped to prevent anaemia. Adding succulent forage to the sows' ration during gestation and lactation reduced piglet deaths post-weaning, while 
adding mineral supplements to pigs' diets helped to tackle diarrhoea (Stewart, 1933; Wye College of Agriculture, 1935, 1938). The effects of respiratory disease could be reduced by lowering the house roof to conserve the pig's natural body heat, and introducing floor to ceiling pen partitions to limit the air-borne spread of infection. Also useful was the addition of covered outdoor yards to pig houses, where pigs could dung and exercise in the fresh air (Anthony, 1935; Price and Ling, 1935-6; Lamont, 1938; Shanks, 1942). There was also the more drastic option of removing air-borne microbes by slaughtering the entire herd and starting afresh with healthy pigs (Beckett, 1935).

The Irish pig producer, Sandy McGuckian, used a combination of these methods. Advised by Lamont, Shanks, and the German pig disease expert Professor Waldmann, who he met on a European tour of pig facilities, he applied the principle of 'isolate and insulate' to his production system. Young pigs were housed with their mothers on pasture in variations of 'Waldmann huts' individual insulated arks made from corrugated iron, with a wooden floor and a sack over the door to conserve heat and prevent draughts. They consumed soil and herbage, which prevented mineral deficiencies. At 8 weeks of age, they were moved into a newly constructed fattening house, specially designed to preserve health by providing warmth, ventilation, dry sleeping quarters, suitable feeding arrangements, adequate lighting, freedom from draughts, drainage, adequate space, and constant water. To prevent the air-borne spread of influenza virus, each pen was constructed as a separate compartment with dividing walls to the roof. Airtight divisions were introduced between pig sleeping quarters, and the feeding and dunging passages. Outdoor yards were added, accessed via trap doors to prevent draughts, and with a covered area to protect from heavy rain and sun. Following these changes, pig mortality halved (McGuckian, 1956; Lamont, 1956). McGuckian (1956, p. 26) later reflected: 'we had changed over from thinking in terms of ill-health and its prevention to the conception of health as a positive thing...the trouble is not in the inherent quality of pigs, but arises from our own incompetence.'

\section{Section 2}

During war-time, the UK pig herd contracted by $65 \%$. Production took place largely in back yards and on mixed farms, as the cereals needed to feed indoor pigs were diverted to human consumption. Concurrently, the diseases of indoor production gave way to digestive complaints caused by swill feeding and worm infestation. These developments reinforced existing associations between pig health and the manner in which they were kept. After the war, the government sought to rectify severe shortages in the nation's meat supply by promoting the production of these rapidly breeding animals. Generous subsidies awarded under the 1947 Agriculture Act, and a 50\% increase in the pig feed ration from 1949, encouraged more farmers to keep more pigs, usually on mixed farms and often in outdoor husbandry systems or adapted buildings. Numbers trebled to over 5 million during the period $1948-54$, providing $20 \%$ of the meat consumed in Britain, at great public cost (Woods, 2012).

The 1957 Agriculture Act aimed to reduce state support and encourage more efficient production methods by reducing subsidies to levels that no longer compensated farmers for their rising costs. While efficiency savings were possible in both extensive and intensive systems of pig production, the Act encouraged the latter. It made available loans for capital investment in housing, and created a new Pig Industry Development Authority (PIDA), which was funded by producer levy to promote technical developments in pig production (Woods, 2012). PIDA assumed responsibility for livestock improvement schemes, and supported near market research into feeding, housing and health. It was particularly concerned with advancing indoor systems of production (Bellis, 1968).

By 1964, the proportion of farms keeping pigs had declined to around $30 \%$, and there was a trend towards larger commercial fattening herds, three quarters of which engaged also in breeding. While the average breeding herd had just 9.5 breeding sows, over the previous 7 years, the number of farms with more than 50 sows had risen by 236 per cent. By 1965, 66\% pigs were in herds of more than 100 compared to $40 \% 10$ years earlier (Pig Farming, 1965a; Juckes, 1967). By 1968 the vast majority of large producers fattened and bred pigs indoors, and relied on feed, or feed supplements purchased from specialist companies like British Oil and Cake Mills (Montague, 2000, pp. 107-14; Woods, 2012). In pig houses, the space allotted per pig shrank to 6 square feet, from 14 square feet in the 1920s. Pigs were now fed on the floor; dung was removed via a central slatted passage, and overhead catwalks were provided to inspect stock and distribute feed (Sainsbury, 1965).

These developments precipitated a decline in pig health. Respiratory and gastro-intestinal diseases re-emerged during the late 1940s and new, puzzling conditions appeared, like oedema disease, a digestive complaint that struck suddenly to kill the best grown pigs at 3-4 months of age. By the 1950s, commentators were routinely highlighting the decline in pig health and regarding it as an apparently inevitable consequence of larger, indoor farming systems (Anthony, 1950; Luke and Gordon, 1950; Various, 1954; Dalling, 1956). Drug therapy offered one possible solution. Available since the late 1930s, the sulphonamides proved effective against certain respiratory diseases. Penicillin, which was developed in war-time and made available to vets during the later 1940s, was used also for this purpose, and to tackle gastro-intestinal diseases (Bud, 2007).

An additional use for antibiotics emerged in the 1950s, after American scientists discovered that administering low doses of aureomycin to apparently healthy pigs promoted their growth. In the belief that this posed no risks to human health and would enhance the food supply (while also boosting the economic performance of British pharmaceutical companies), the government agreed in 1953 to permit the addition of low dose aureomycin to pig and poultry feeds. Pharmaceutical companies intensively advertised the financial benefits of this feed to farmers (Finlay, 2004; Berdah, 2011; Kirchhelle, 2018b), and by 1958, around half of the pigs in Britain and nearly all unweaned piglets had access to it (Williams Smith, 1958). No veterinary prescription was required for antibiotics added to food. However, only vets could supply them in the larger doses required to treat disease. Vets were also gatekeepers of a new vaccine released in 1947 that protected pigs against the highly prevalent, contagious swine fever (Wilsdon, 1958). Consequently, pig farmers began to employ them more frequently, which in turn encouraged vets to take a greater interest in pig diseases and to expand their scientific investigations (British Veterinary Association, 1947; Ministry of Agriculture and Fisheries, 1954, 1955, 1956; Field, 1964).

Politicians and journalists were extremely enthusiastic about the potential of antibiotics to address post-war food shortages (Kirchhelle 2018a, 2018b). Some farmers also acknowledged their importance in sustaining more intensive methods of production. References to the increased veterinary income derived from drugs, and to farmers as 'drug addicts' confirm their popularity, as does the massive expansion of the veterinary medicines industry (Hope, 1961; Swann, 1963; Pig Farming, 1964a; Corley and Godley, 2011). However, contributors to the pig farming and veterinary press displayed little of the unbridled optimism that present-day commentators tend to associate with early antibiotic uses. In fact, they were rather critical of antibiotics and sought to 
minimise consumption. Historians have tended to associate such attitudes with the discovery of antibiotic residues in food, the development of antimicrobial resistance, and fears about the implications for animal welfare of antibiotic-dependent intensive systems (Bud 2007; Kirchhelle 2018a, 2018b). That was not the case here, however. The first of these problems was peripheral to the pig industry. The others were mentioned only occasionally, and largely in reference to the use of antibiotics as growth promoters, for example when David Sainsbury (1965, p. 390), a Cambridge veterinary expert in pig housing, reported the development of resistance to certain intestinal infections, and complained that producers were often using antibiotics haphazardly: 'in one sense they form a 'cover up' for errors in management.' The main reason why pig producers and vets proved sceptical of antibiotics was because they were incapable of curing some of the most prevalent and costly diseases of intensive pig production.

For some of these diseases, symptoms could be mitigated by antibiotic treatment, but this was extremely expensive and recovered pigs were often chronically unthrifty and unprofitable to fatten (British Veterinary Association, 1956; Horvat, 1960). Other diseases were precipitated by viruses and other microbes which antibiotics were incapable of killing. The identity of these disease agents, and their involvement in what came to be regarded as respiratory or gastro-intestinal disease complexes, was increasingly recognised from the late 1950s. This was due partly to the development of new laboratory techniques for culturing, titrating and visualising viruses, and the associated development of virology as a specialist field of enquiry (Hughes, 1977). Antibiotic use was also a factor in removing the more controllable, bacterial elements of respiratory and gastro-intestinal diseaseswhich had contributed significantly to inter-war pig mortality-it brought to light a host of residual, viral disease agents whose presence and health impacts had previously been disguised. The growth of intensive production systems also meant that these agents were becoming more prevalent and their effects more noticeable, resulting in the identification of a new category of diseases in which they were heavily implicated: 'diseases of production' (Paterson, 1973).

Diseases of production were characterised by complex aetiologies, low mortality, mild clinical signs, and a loss of productive capacity. Although rarely fatal, they were extremely common, which meant that cumulatively, they impacted significantly on productivity and profit, and undermined pig breeders' efforts to select and breed from the fastest-growing animals (Sainsbury, 1957; Pig Farming, 1959; Done, 1962; Paterson, 1973). Sainsbury (1957, p. 44) noted that even without changes in management, 'As soon as pigs are kept together in large numbers, this... will predispose them to diseases, such as respiratory ailments... which may never have been seen before on the farm. It seems, therefore, as though you can keep too many pigs together.' The situation worsened as production became more intensive. Increased pig stocking densities and the mixing of susceptible pigs led to a build-up of pathogens that could interact to cause disease (Anon, 1966). Its effects were particularly noticeable in intensive indoor systems because here, pig growth rates relative to food consumed were closely monitored, and the entire operation disrupted if pigs did not grow or farrow to schedule (Johnson, 1959).

In his history of penicillin, Robert Bud argues that antibiotics diverted attention from hygienic practices by transforming infection into a technical problem that was susceptible to a pharmaceutical solution (Bud 2007, pp. 98-99). However, the above evidence reveals that in pig farming, this transformation was incomplete. Antibiotics were not a straightforward solution to disease. Their limitations reinforced the pre-existing concept of pig disease as a complex multi-factorial product of the relationship between pig bodies and their environments, and refocussed attention on hygiene and other factors that could prevent or precipitate it. Reg Goodwin (1957, p. 1295), a specialist pig vet and Cambridge University lecturer, warned of the 'danger that in the age of antibiotics too much emphasis can be given to treatment; it is often simpler to create conditions to prevent unthriftiness than to cure it.' Other vets and farmers highlighted how disease susceptibility and severity was enhanced by the indoor pig's dependence on rations, which often resulted in slight anaemia and vitamin deficiencies, and by its confinement in substandard housing which resulted in a lack of exercise and exposure to chilling, draughts and sudden temperature changes (Pig Farming, 1957a; Anon, 1966). Leaders of the veterinary profession responded to this situation by attempting to position themselves as expert advisers on feeding, breeding, housing and pathogen control, rather than as a 'fire brigade' service that used drugs to treat disease (Woods, 2013). The final section of this paper will explore some of the solutions that they and UK pig farmers developed for one particularly problematic disease of production known as Virus Pneumonia of Pigs (VPP).

\section{Section 3}

Of all the pig diseases experienced by intensive pig producers, VPP attracted the greatest attention during the 1950s and 1960s. ${ }^{3}$ This was due its high prevalence and costly impacts, its enhanced visibility as antibiotics removed bacterial pneumonias from the disease picture, and the frequent scientific investigations performed on it, most notably at the newly established Cambridge University School of Veterinary Medicine, which was situated close to the East Anglian pig herds that made up 20\% of the UK pig population. ${ }^{4}$ These studies differentiated VPP from the more widely recognised pig influenza (Betts, 1952). They showed that its impacts varied by husbandry methods and the time of year. Pigs kept in cold, draughty indoor fattening houses were especially badly affected, while those contracting disease in the summer suffered less serious effects. Measurements suggested that infection caused a $25 \%$ reduction in feed conversion. Considered alongside post-mortem lung inspections which suggested that around $50 \%$ of UK pigs had been exposed, this indicated that in 1953 alone, VPP cost the nation $£ 15.6 \mathrm{~m}$ (Betts and Beveridge, 1953; Betts et al. 1955). As profit margins narrowed, the effect of VPP became relatively more significant. By 1962, it was argued that it could make the difference between farming profit and loss (Barr, 1962).

One obvious solution, devised during the inter-war period, was to breed and rear pigs outdoors. From the 1950s, this method found new applications on mixed farms under the 'Roadnight system', which is still applied today. Devised by Richard Roadnight on his farm near Watlington, Oxfordshire, it employed pigs instead of sheep as a break crop on arable land. ${ }^{5}$ Sows were run in large groups on fenced paddocks and housed in arcs made initially from old corrugated iron Anderson air-raid shelters. They produced two litters of piglets a year, which were sold or moved into an indoor fattening house at 8 weeks of age. This system required light, free-draining soil in a low rainfall area, so was adopted mostly in Southern England, East Anglia, and on the eastern side of the country as far north of Aberdeen. By the 1960s, around $5 \%$ of UK breeding sows were kept in this way, often in very large herds. A number of other producers did so in the summer months, to rest and clean their pig houses. While erecting the necessary fencing was laborious and expensive, costs of feed and housing were extremely low. Pigs were also remarkably healthy. One study reported that the number of veterinary consultations per 10 sows per year was $90 \%$ less than in conventional systems, and that VPP was never a problem (Juckes, 1967; Farm Animal Welfare Council, 1996, pp. 3-4). 
However, for many pig producers, it was simply not possible to move pigs outdoors. They did not have land, or the right type of land, and as pig housing became more elaborate and expensive they were unwilling to write off the substantial investment they had already made. They needed to elevate pig health and productivity within existing systems of housing and management (Pig Farming, 1957b). ${ }^{6}$ The Cambridge veterinary experts Ian Beveridge (better known for his work on swine influenza), Alan Betts and Pete Whittlestone, answered this need by devising a method of establishing VPP-free herds. This was very difficult, as a high proportion of pigs carried the disease, often without displaying symptoms. Its microbial agent could not be isolated or cultured, therefore detection relied heavily on the identification of pathological changes in pig lungs at post-mortem. By farrowing sows in isolation, monitoring the clinical condition of their litters, and sacrificing at least one piglet to check its lungs, it was possible to identify uninfected mothers whose offspring could form the nucleus of a new, healthy herd (Betts et al. 1955; Whittlestone and Betts, 1955).

At the request of leading pig breeders, who came together to form an 'Association for the Advancement of Virus Pneumonia Free Pigs' (AAVPFP), Whittlestone and his fellow lecturer, Reg Goodwin formalised this method into a scheme for the production and certification of VPP-free herds. Once herds were free from VPP, they were checked at intervals - in life and death - for signs of re-infection (Veterinary Record, 1958; Goodwin, 2009). Participants in the AAVPFP saw it as means of securing market advantage. As commercial producers, they wanted their pigs to grow faster and reach market weight quicker, while as pedigree breeders, they wanted to sell healthy stock at a premium and be sure of the health status of those they purchased. The association devised a VPP-free logo for members to use in their advertising and published a 6-monthly register of disease-free member herds. Paradoxically, because VPP was more of a problem under intensive conditions, its regulations subjected pigs fattened in healthier, outdoor systems to more stringent checks in order to declare them VPP-free (Veterinary Record, 1958; Goodwin and Whittlestone, 1960; Goodwin, 2009).

Considerable outlay was required to establish a VPP-free herd. Membership of the Association was expensive, and breakdowns were not uncommon. To prevent the re-entry of VPP, members were required to maintain closed herds with the exception of pigs purchased from other members. This was an unusual practice c.1960, and at a time when artificial insemination was in its infancy, it limited the prospects for genetic improvement. Nevertheless, the Association acquired a following of over 100 leading pig breeders and several agricultural colleges and research institutes. Its members argued that because commercial producers purchased breeding pigs from their herds, the Association benefitted the industry as a whole (AAVPFP, 1961; Goodwin and Whittlestone, 1967; Brassley, 2007; Goodwin, 2009).

During the early 1960s, Betts introduced from the USA another method of eliminating VPP and other diseases from pig herds. It derived from an experimental method used to produce pathogenfree laboratory animals for scientific research (Kirk, 2012). Hysterectomies were performed on sows under strict aseptic conditions, and the piglets reared artificially in incubators and brooder cages to protect them from infectious diseases like VPP that they normally contracted from their mothers or the environment. The offspring of these piglets-which had a slightly lower health status because certain infections were contracted inevitably throughout life-were sold as 'Minimal Disease' (MD) or 'Specific Pathogen Free' (SPF) pigs, and could be used to create new, healthy herds (Done, 1955; Betts et al. 1960; Betts, 1961).

By 1961, Stephen Horvat, one of the leading spokesmen of intensive production, had established Britain's first commercial
MD herd (Pig Farming, 1962a), and two companies had formed to produce MD pigs for the market. The Pig Hysterectomy Company (PHC) was created by elite breeders, who enroled Goodwin as their veterinary advisor. Betts was the veterinary brainchild of the Specific Pathogen Free Company, whose advertising invited producers to 'Be tomorrow's farmer today' and to 'revolutionise British pig production' (Pig Farming, 1963; Goodwin, 2009). It offered to produce MD piglets at a cost of $£ 15$ from sows provided by the farmer and claimed that their rate of food conversion was $15 \%$ higher than that of normal healthy pigs. Betts recommended farmers who founded MD herds to preserve their health status by disinfecting buildings, controlling birds and vermin, and banning visitors or requiring them to use boots and overalls (Betts, 1961; Haynes, 1963a, 1963b).

Although Goodwin and Betts were involved in both initiatives, the former became the spokesmen for the Association and the latter for the SPF/MD movement. There were philosophical and personal differences between them. Goodwin argued that the terms 'MD' or 'pathogen free' were problematic as they did not state exactly what pathogens pigs were free from. Since the microbial causes of certain diseases were unknown, and there was no requirement for $\mathrm{MD}$ herds to undergo periodic checks of health status, it was impossible to say what this designation actually meant. He pointed out that VP had appeared in several such herds despite their strict hygiene, and argued that such pigs should simply be referred to as 'hysterectomy produced'-hence the name of his company. He also cast doubt on whether the health gains over and above VPP eradication were sufficient to justify the highly elaborate and costly method of production (Goodwin and Whittlestone, 1961; Goodwin, 1961; Goodwin, 2009).

For many elite breeders, MD pigs and the AAVPFP offered complementary routes to health: membership of the association allowed them to monitor the VPP status of pigs produced via the $\mathrm{MD}$ route, and to introduce new genetics into the herd (Pig Farming, 1962; Horvat, 1964). However, PIDA's veterinary committee displayed a distinct preference for $\mathrm{MD}$ pigs and resisted ongoing calls to bankroll the AAVPFP. Committee members were on close terms with Betts. They valued the international recognition of the MD method, and the fact that production was veterinary-led and could potentially be controlled by licensing. Their relations with Goodwin were more fraught, and they disliked the private, farm-led nature of the Association, which ran contrary to the public, veterinary-led ethos of post-war animal health services (PIDA, 1961-3; Veterinary Consultant, 1963, Woods, 2013). In 1964, perhaps in response to the competition posed by MD herds, the Association began to incorporate other diseases in its health scheme, and changed its name to the Pig Health Control Association (PHCA). This caused further difficulties with MAFF and PIDA, by interfering with plans to develop a Pig Health Scheme of their own (Ministry of Agriculture, 1964-5).

Advocates of VPP-freedom argued that it enabled pigs to produce efficiently under sub-optimal conditions of housing and management. However, other vets and producers debated whether it was practical or economical to invest in VPP-free herds, especially given their vulnerability to reinfection (Pig Farming, 1962b; Editorial, 1963; Pig Farming, 1964b). Some claimed that the improved performance of these herds was due not to the absence of pathogens, but to the management and hygiene practices adopted in a bid to keep disease out (Melrose, 1965). Others pointed out that the elimination of VPP did not abolish pig respiratory disease. Rather, as with antibiotic use, it unmasked other respiratory conditions that had previously been conflated with it (Reporter, 1963; Field, 1964). Veterinary researchers subsequently identified a multi-microbial respiratory disease 
complex, whose viral, bacterial and parasitic components varied between herds, and whose impact on pig health and productivity was influenced by management factors (Melrose, 1964; Little, 1972).

The prevailing multi-causal view of pig diseases lay at the heart of these criticisms. One veterinary researcher pointed out that 'the single minded search for a consistent [microbial] isolate....has obscured the important fact that a disease process may be the result of a combination of factors' (Jericho, 1968, p. 511). While supporters of VPP-freedom argued that removing pathogens enabled pigs to thrive under sub-optimal conditions, critics argued the reverse: that optimal housing and management could substitute for VPP-freedom by enabling pigs to thrive regardless of disease. They pointed out that under such conditions, VPP had little impact, whereas if husbandry was poor it inflicted greater losses (Gordon and Luke, 1955; Whittlestone, 1957; Field, 1964; Horvat, 1964).

These observations raised the question of what form of housing could neutralise the effects of VPP. The answer was not clear cut. In the post-war decades, pig housing was in a state of flux. Scientific research was expanding at various veterinary schools and a new Department of Farm Buildings at the North of Scotland Agricultural College. It produced in a host of technical, quantitative analyses of air flow rates and patterns, temperatures, heat loss, humidity, building materials, odour and cubic space allocations (Soutar, 1953; Gordon, 1962; Sainsbury, 1963). However, translating these findings into practice was a difficult task. The editor of Pig Farmer (1959) reported that there was no standardtype pig house that could produce all-round results under general farm conditions. Many different forms of building were in use, some designed by farmers, others with the advice of vets and architects, and many ran into difficulties with disease. Ultimately, no-one could say for certain what constituted a good pig house, except that it was a house in which pigs could be produced profitably. Nevertheless, there were certain preconceived notions of what conditions would promote health, and the housing method that emerged as particularly effective in combating VPP seemed to challenge them all.

This was the 'sweat box' method devised by Jimmy Jordan, the owner of a 4000 pig herd in County Down. He had noticed that VPP seemed to impact less on production during the summer, and in pig houses fouled by dung and urine. As an experiment, he lowered the pig house roof, sealed the door and closed the windows. The detrimental effects of VPP seemed to disappear, leading him to apply these conditions wholesale. The temperature in sweat boxes was extremely high, and humidity approached $100 \%$, resulting in a steamy and gloomy environment, and wet floors and walls that glistened with slime. Stocking density was up to four times that of other indoor systems. Meal was dumped on the floor, there were no separate dunging passages, and there was no cleaning between the entry and exit of each batch of pigs. These conditions contravened all precepts of good husbandry and yet they achieved levels of productive efficiency that were rarely equalled by conventional methods. Despite the difficulty in finding staff willing to work under such conditions, the 'sweat box' proved popular in Ireland, and 25-30 producers had adopted it on the mainland by 1965 (Hogley, 1956; Pig Farming, 1961; Technical Committee, 1965, pp. 31-32; Meredith, 2009).

Government veterinary researchers in Northern Ireland investigated these surprising effects (Gordon and Luke, 1956, p. 1030-1031). They hypothesised that heat and humidity swelled the infected particles in the air, enabling them to be filtered out by the tonsils. They concluded: 'It is important not to evaluate this environment from the standpoint of human preference but from the aspect of pig comfort and wellbeing.' This was precisely why Ruth Harrison criticised it in her book, Animal Machines (1964).
Her account of the threats posed to animal welfare by this and other intensive farming practices attracted considerable public attention, and led the Ministry of Agriculture to appoint a technical committee to examine the welfare of animals kept in intensive conditions (Sayer, 2013). Chaired by zoologist, Rogers Brambell, it highlighted the many problems with sweat boxes. The darkness made it impossible to inspect stock and to detect ailing animals. To avoid death by heatstroke, skilful management of the temperature was required. To avoid over-heating, pigs were forced to spend time lying down, but had hardly any space and quickly became covered in excreta, which also contaminated their food (Technical Committee, 1965, pp. 31-32). Even the Ministry of Agriculture, which was generally hostile to criticisms of intensive farming practices, took a dim view of sweat boxes, with one official describing them as 'nauseating Belsens' (Winnifrith, 1966).

The committee was more positive about the MD method of managing VPP (Technical Committee, 1965). However, by the mid-1960s, both of the commercial companies set up to supply MD pigs had folded. Production had proved more expensive than anticipated, and the advertised performance gains were not realised (PIDA, 1964; Goodwin, 1965). Nevertheless, MD pigs did take off in the hands of specialist breeding companies, which were beginning to gain market share. They used population genetics to select top performing pigs, which they kept in MD herds and crossed to produce hybrids, whose superior health and genetics enabled them to outperform conventional pigs. These companies eventually became the main source of fattening pigs in the UK (Pig Farming, 1965b; Bichard, 1978). The question of what diseases MD pigs were actually free from remained unclear, however, and as Hinchliffe and Ward have shown (2014), this remains the case today. The former AAVPFP survived until 1993, but its ability to control VPP declined over time, as increases in herd size and stocking density resulted in greater volumes of airborne pathogens, which posed a growing threat to herds attempting to remain free of the disease (Goodwin, 2009; Meredith, 2009).

\section{Conclusion}

The rising threat of antimicrobial resistance means that antibiotic use in agriculture is now attracting an unprecedented degree of attention from academics, policy makers and publics. Research and commentary focuses overwhelmingly on antibiotics as growth promoters and their implications for human health. As a counterbalance, this article has foregrounded the therapeutic uses of antibiotics and their contributions to animal health. Taking issue with the widely claimed but rarely investigated relationship between antibiotic consumption and intensive livestock production, it has explored the co-evolution of pig health and production practices, and located antibiotics within the wider landscape of farming and veterinary responses to the diseases of intensive farming. In the process, it has restored the voices of farmers to a historical record that is overwhelmingly dominated by scientific experts and policy makers.

This perspective has shown that while antibiotics were certainly used in intensive systems, they were neither necessary nor sufficient for the production of healthy pigs. 'Factory-style' pig farming pre-dated their discovery and was maintained in spite of the associated decline in pig health. Even when antibiotics became available, they proved incapable of controlling some of the most economically significant diseases of intensive pig production. This was not due to the development of antimicrobial resistance, but because many diseases were not susceptible in the first place. Scientific research and empirical experience showed that these diseases were highly complex, the products of the interacting 
effects of environment, husbandry, nutrition and microbes on pig bodies. At best, antibiotics could address one component of this nexus. Their limitations enhanced awareness of disease complexity, and boosted the search for alternative control methods that aimed to eradicate germs and/or improve husbandry.

These findings challenge a number of claims that medical historians have made of antibiotics: that these drugs were widely embraced until the discovery of residues, AMR and emergence of animal welfare concerns; that antibiotics reinforced reductionist understandings of disease as the product of pathological agents invading susceptible bodies, and that they encouraged the neglect of hygienic approaches to disease prevention and control. Other historians have argued that in the mid-20th century, a holistic view of disease was counter-cultural, an expression of resistance to modernity (Lawrence and Weisz, 1998; Anderson, 2004). In the context of pig production, however, it was the very apogee of modernity, a view embraced by industry leaders and the emerging breed of veterinary experts centred particularly in Cambridge veterinary school. These parties devised a range of disease control methods that predated antibiotics, evolved alongside them, and often proved effective in containing the diseases of intensive production.

Some disease interventions aimed to strengthen pig bodies to better withstand infection; others were intended to reduce exposure to pathogenic microbes. The outdoor systems devised by McGuckian and Roadnight were widely regarded as effective solutions, though economic and environmental pressures did not always permit their adoption. In indoor systems, pig health could be improved by adopting the housing adjustments recommended by Luke, Sainsbury and sweat box farmer, Jimmy Jordan. Producers could also free their herds from certain diseases by purchasing MD pigs or enroling in the farmer-run AAVPFP. Some of these methods - notably the Roadnight system and MD pigs-are still used today.

Therefore, the health of pigs in intensive farming systems was not as dependent on antibiotics as historians and contemporary commentators have tended to assume. It is important to recognise that antibiotics were not the only or even the most important means of advancing pig health, and that many other methods were used-and continue to be used today. This finding not only challenges the historical narrative surrounding antibiotics and intensive livestock farming; it also suggests considerable grounds for optimism as we move into a post-antibiotic world. Extending the use of existing non-antibiotic methods of promoting livestock health, searching out new ways of addressing the multi-factorial nature of production diseases, and re-examining the merits of methods abandoned over time could help profitable production to continue in a post-antibiotic era. While animal welfare prevents re-adoption of the sweat box, there may be elements of this system, the abandoned AAVPFP, and other methods mentioned in this article that could enhance the future health of pigs. Further insights could be developed by more in-depth archival investigations into the contributions made by husbandry to livestock health, and through dialogue with farmers and vets in a programme of interviews that would capture their memories. The latter would be particularly useful in speaking to present-day vets and farmers, including those who argue against antibiotic reduction targets.

The history of mastitis, a production disease of dairy cattle, suggests that in Britain, holistic conceptions of disease and approaches to its management were not confined to pig production, or indeed viral diseases. Although the bacteria responsible for mastitis were amenable to antibiotic therapy, this did not solve the disease problem. Rather, as in pigs, the removal of certain bacterial components paved the way for the emergence of other microbes, which prompted the development of various environmental interventions (Woods, 2014). Bowmer's study of phenothiazine (2018) suggests that attitudes to other antimicrobial drugs were similarly mixed. Predating penicillin by at least a decade, phenothiazine was sold as a 'magic bullet' against internal parasites, but farmers continued to use existing environmental interventions and patent remedies alongside it, especially on discovering that its efficacy seemed to be declining - an observation which alerted the drug company, Boots to the development of antimicrobial resistance. Additional studies of this kind, relating to livestock production in the UK and other countries, are now required, to further test received views about the role of antibiotics and AMR in the development of livestock intensification, and to provide examples of past approaches to disease control which may find renewed applications in a postantibiotic world.

\section{Data availability}

Data sharing is not applicable to this article as no datasets were generated or analysed during the current study.

\section{Received: 9 September 2018 Accepted: 18 March 2019}

Published online: 23 April 2019

\section{Notes}

1 These features have also inspired analyses of contemporary pig production. See especially Hinchliffe and Ward, 2014; and Blanchette, 2015.

2 Grade was defined by back fat thickness, which varied considerably among pigs. Higher grades were achieved by leaner pigs, whose bacon was more popular with consumers (Davidson, 1948; Higgins and Mordhorst, 2015).

3 The disease was subsequently renamed Enzootic Pneumonia and its agent reclassified as a mycoplasma. In combination with secondary pathogens which were not recognised until the 1970s, it remains a major cause of production loss today (White, 2018).

4 Cambridge vets who became renowned for their pig expertise included Alan Betts, Reg Goodwin, Pete Whittlestone, Tom Alexander, Peter Storie Pugh, W Ian Beveridge and David Sainsbury. Most focussed on pig diseases, though Sainsbury was an expert in housing. Pugh and Beveridge were also pedigree pig breeders.

5 A break crop interrupted cycles of arable production and was intended to break cycles of pests, diseases and weeds

6 Juckes argued in 1967 that it took 10 years for those investing in specialist housing to receive a return on their capital (Juckes, 1967).

\section{References}

AAVFPP (1961) Request from the association for financial support, 11 June. TNA MAF $189 / 935$

Agricultural Research Council (1933a) Minutes of the first meeting of the Committee on Pig Diseases, 10 Jan. TNA MAF 33/710

Agricultural Research Council (1933b) Conference on pig research, 31 May. TNA MAF 189/94

Agricultural Research Council (1938a) Minutes of the tenth meeting of the Committee on Pig Diseases, 21 Dec. TNA MAF 189/255

Agricultural Research Council (1938b) Fifth interim report of the Committee on Pig Diseases, 17 Oct. TNA MAF 189/255

AHDB Pork (no date) Pig Production. https://pork.ahdb.org.uk/pig-production/. Accessed 8 Sept 2018

Allen T (1910) Profitable pig breeding and feeding. L Upcott Gill, London

Amsterdamska O (2001) Standardising epidemics: infection, inheritance and environment in prewar experimental epidemiology. In: Gaudilliere J-P, Lowy I (eds) Hereditary and infection: the history of diseases transmission. Routledge, London, 135-79

Anderson G (1961) The veterinary profession, past, present and future. Veterinary Record 73:187

Anderson W (2004) Natural histories of infectious disease: ecological vision in 20th century biomedical science. Osiris 19:39-61

Andrews WH (1934) Government correspondence, 20 April. TNA MAF 33/710

Anon (1966) The price of concentration. Pig Farming 14(6):42-43

Anthony DJ (1935) Some notes on swine practice. Veterinary Record 47:75-84

Anthony DJ (1940) Diseases of the pig and its husbandry. Balliere and Co, London

Anthony DJ (1950) Some aspects of pig production and disease. Veterinary Record $62: 39-43$ 
Barr D (1962) Muck and money. Pig Farming 10(1):29

Barton Mary (2014) Impact of antibiotic use in the swine industry. Curr Opin Microbiol 19:9-15

Beckett F (1935) Some pig diseases. Veterinary Record 47:415-21

Bellis DB (1968) Pig farming in the United Kingdom-Its development and future trends. J R Agric Soc Engl 129:24-42

Berdah D (2011) Antibiotics in British farming, 1945-1959: The construction of a pharmaceutical market between clinic, preventive medicine, and animal nutrition. Paper presented at "Beyond the magic bullet: Reframing the history of antibiotics". ESF Conference, Oslo

Betts AO (1952) Respiratory diseases of pigs. Veterinary Record 64:283-88

Betts AO (1961) Pathogen-free pigs for research and the practical control of pig diseases. Veterinary Record 73:1349-61

Betts AO, Beveridge WIB (1953) Virus pneumonia of pigs: the effect of the disease upon growth and efficiency of food utilisation. Veterinary Record 65:515-20

Betts AO, Lamont PH, Littlewort MGC (1960) The production by hysterectomy of pathogen free, colostrum deprived pigs and the foundation of a MD herd. Veterinary Record 72:461-68

Betts AO, Whittlestone P, Beveridge WIB (1955) Investigations on the control of virus pneumonia of pigs in the field. Veterinary Record 67:685-9

Betts AO, Whittlestone P, Beveridge WIB, Taylor JH, Campbell RC (1955) Virus pneumonia of pigs: further investigations of the effect of the disease upon the growth rate and efficiency of food untilisation. Veterinary Record 67:661-65

Bichard M (1978) Pig testing http://www.nsif.com/conferences/1978/British\%20Pig \%20Testing,\%20Reproduction\%20and\%20Sow\%20Productivity.pdf. Accessed 8 Sept 2018

Blanchette A (2015) Herding species: biosecurity, posthuman labor, and the American industrial pig. Cult Anthropology 30:640-69

Bowmer A (2018) A view from the farm: antimicrobial resistance before antibiotics, c1940-1960. Paper presented to the Annual Conference of the British Society for the History of Pharmacy

Boyd Orr J (1935) The newer knowledge of nutrition. Farmer and Stockbreeder, 29 April, supplement $\mathrm{p}$ xxxix

Brassley P (2007) Cutting across nature? The history of artificial insemination of pigs in the United Kingdom. Stud Hist Philos Biol Biomed Sci 38:442-61

British Veterinary Association (1947) Report on diseases of farm livestock, section v- The husbandry and diseases of pigs. 1st edn., BVA publications, London

British Veterinary Association (1956) Report on diseases of farm livestock, section $\mathrm{v}$ - The husbandry and diseases of pigs. 3rd edn., BVA publications, London

Brooks EW (1935) Outdoor systems for pigs. Farmer and Stockbreeder 27 May, p. 1157

Brooksbank N (1937) Provisional report of survey on disorders of young pigs. TNA MAF 33/710.

Bud R (2007) Penicillin: triumph and tragedy. Oxford University Press, Oxford

Corley T, Godley A (2011) The veterinary medicines industry in Britain, 1900-2000. Econ Hist Rev 64:832-54

Dalling T (1956) The impact of modern farm husbandry on animal health. Marjory Boyd, Belfast

Davidson HR (1935) Common sense pig recording. Farmer and Stockbreeder 8 April, p. 793

Davidson HR (1948) The production and marketing of pigs. Longmans Green \& Co, London

Done JT (1955) Aseptic delivery and artificial rearing: a technique for disease control in pigs. Veterinary Record 67:623-25

Done JT (1962) Some pig disease problems in Britain. N Z Vet J 10:71-78

Editorial (1959) Housing the pig. Pig Farming 7(7):17

Editorial (1963) Let's get on with it. Pig Farming 11(2):17

Farm Animal Welfare Council (1996) Report on the welfare of pigs kept outdoors. FAWC,

London, https://assets.publishing.service.gov.uk/government/uploads/system/uploads/ attachment data/file/325253/

FAWC_report_on_the_welfare_of_pigs_kept_oudoors.pdf. Accessed 8 Sept 2018

Farmer and Stockbreeder (1921) A modern piggery: some details of construction. Farmer and Stockbreeder 25 April, p. 1653

Field HI (1964) Diseases of pigs. HMSO, London

Finlay M (2004) Hogs, Antibiotics and the industrial environments of post war agriculture. In: Schrepfer S, Scranton P (eds) Industrializing organisms: introducing evolutionary history. Routledge, London, p 237-60

Fishwick VC (1935-36) The management of growing pigs: outdoor v indoor systems J Ministry Agric 42:345-52

Foot AS, Kon SK (1938-39) Vitamin supplements in practical pig feeding J Ministry Agric 45:913-19

Forman C (1937) Pig breeding and feeding. Faber \& Faber, London

Garrad GH (1933) Pig recording means efficiency. Farmer and Stockbreeder 6 Feb, p. 299

Goodwin RFW (1957) Some diseases of suckling pigs. Veterinary Record 69:1290-98
Goodwin RFW (1961) Response to A O Betts, Pathogen-free pigs for research Veterinary Record 73:1358-9

Goodwin RFW (1965) The possible role of hysterectomy and related procedures for the eradication and control of pig diseases in Britain. Veterinary Record 77:1070-76

Goodwin RFW (2009) Interview with Abigail Woods, 26 June

Goodwin RFW, Whittlestone P (1960) Experiences with a scheme for supervising pig herds believed to be free from enzootic pneumonia (virus pneumonia). Veterinary Record 72:1029-52

Goodwin RFW, Whittlestone P (1961) Hysterectomy and disease control in pigs. Veterinary Record 73:512-13

Goodwin RFW, Whittlestone P (1967) The detection of enzootic pneumonia in pig herds: 8 years general experience with a pilot control scheme. Veterinary Record 81:643-47

Gordon WAM (1962) Environmental studies in pig-housing. Br Vet J 118:171-205, 243-56

Gordon WAM, Luke D (1955) The impact of environment on the health and productivity of pigs. Veterinary Record 67:1007-10

Gordon WAM, Luke D (1956) Observations on restricted ventilation in pig houses. Veterinary Record 68:1030-31

Harrison R (1964) Animal machines: the new factory farming industry. Vincent Stuart, London

Haynes C (1963a) Banishing the bugs. Pig Farming 11(1):32-33

Haynes C (1963b) Space age pigs. Pig Farming 11(2):40-43

Higgins DM, Mordhorst M (2015) Bringing home the 'Danish' bacon: food chains, national branding and Danish supremacy over the British bacon market, $c$. 1900-1938. Enterprise Soc 16:141-85

Hinchliffe S, Ward K (2014) Geographies of folded life: how immunity reframes biosecurity. Geoforum 53:136-44

Hogley BT (1956) 4000 baconers thrive in high humidity houses. Pig Farming 1956 (8):31

Honigsbaum M (2016) 'Tipping the balance': Karl Friedrich Meyer, latent infections, and the birth of modern ideas of disease ecology. J Hist Biol 49:261-309

Hope J (1961) John Hope's page. Pig Farming 9(10):33

Horvat S (1960) Secrets of success in pig keeping. Pig Farming 8(2):39

Horvat S (1964) The economics of husbandry and the disease pattern in pigs. Veterinary Record 76:1181-89

Hughes S (1977) The virus: a history of the concept. Heinemann Educational Publishers, London, p 97-105

Jericho KWF (1968) Pathogenesis of pneumonia in pigs. Veterinary Record 82:507-20

Johnson G (1959) Profitable pig farming. Farming Press, Ipswich

Jones S (2003) Valuing animals: veterinarians and their patients in modern America. John Hopkins University Press, London, p 91-114

Juckes D (1967) Scale of enterprise and structural change in British pig farming. University of Exeter, Department of Agricultural Economics, Exeter

Kirchhelle C (2018a) Swann song: antibiotic regulation in British livestock production (1953-2006). Bulletin of the History of Medicine 92(2):317-50

Kirchhelle C (2018b) Pharming animals: a global history of antibiotics in food production (1935-2017) Pal Commun 4: https://doi.org/10.1057/s41599-018$0152-2$

Kirk R (2012) Standardization through mechanization: germ-free life and the engineering of the ideal laboratory animal. Technol Cult 53:61-93

Lamont HG (1938) The problems of the practitioner in connection with the differential diagnosis and treatment of diseases in young pigs. Veterinary Record 50:1379-400

Lamont HG (1956) Pig housing and health. In: Muskett AE (ed) A.A. McGuckian: a memorial volume. McGuckian Memorial Committee, Belfast, p 105-22

Lamont HG, Luke D, Gordon WAM (1950) Some pig diseases. Veterinary Record 62:737-56

Lawrence C, Weisz G (eds) (1998) Greater than the parts: holism in biomedicine. Oxford University Press, Oxford, p 1920-50

Little TWA (1972) A study of progressive respiratory disease in pigs. TNA MAF $364 / 72$.

Luke D, Gordon WAM (1950) Observations on some pig diseases. Veterinary Record 62:179-85

McGuckian S (1956) Housing for health in pig production. In: Muskett AE (ed) A. A. McGuckian: a memorial volume 1956. McGuckian Memorial Committee, Belfast, p. 25-34

Melrose (1964) Respiratory disease research. Memo VA 412, 2 December. TNA MAF $189 / 939$

Melrose D (1965) Preventive methods in pig farming. Veterinary Record 77:1361-62

Mendelsohn JA (1998) From eradication to equilibrium: how epidemics became complex after World War I. In: Lawrence C, Weisz G (eds) Greater than the parts: holism in biomedicine 1920-50. Oxford University Press, Oxford, p. 303-34

Meredith, M (2009) Interview with Abigail Woods, 26 June 
Ministry of Agriculture and Fisheries $(1954,1955,1955)$ Annual report of proceedings under the Diseases of Animals Acts. HMSO, London

Ministry of Agriculture and Fisheries (1964-5) Correspondence relating to the Pig Health Control Association. TNA MAF 287/245.

Montague D (2000) Farming, food and politics: a merchants' tale. IAWS Group, Dublin

O'Neill J (2016) Tackling drug-resistant infections globally: final report and recommendations. The review on antimicrobial resistance. https://amrreview.org/sites/default/files/160518_Final\%20paper_with\%20cover.pdf. Accessed 8 Sept 2018

Parrot H (2018 Antibiotics use halved in the pig industry over two years. Farmers Weekly May 16. https://www.fwi.co.uk/livestock/antibiotic-usage-halved-pigindustry-two-years. Accessed 8 Sept 2018

Paterson A (1973) Animal health. Phil Trans R Soc London B 267:113-30

PIDA Veterinary Advisory Committee (1961-3). Minutes of meetings. NA MAF 189/936, 937 and 938

PIDA Veterinary Advisory Committee (1964). Minutes of 32nd meeting, 8 December. TNA MAF 364/28

Pig Farming (1957a) Report of Harper Adams pig conference. Pig Farming 5 (9):24-25

Pig Farming (1957b) Respiratory diseases of pigs. Pig Farming 5(11):43-44

Pig Farming (1959) They pointed the way to more profit per pig. Pig Farming 7 (12):49-50

Pig Farming (1961) The facts about sweat box piggeries. Pig Farming 1961 (9):53-55

Pig Farming (1962a) The Clearway herd of MD pigs. Pig Farming 10(6):3

Pig Farming (1962b) The rise of the MD pigs. Pig Farming 10(8):28-32

Pig Farming (1963) Advertisement for SPF Pigs Ltd. Pig Farming 11(4):56

Pig Farming (1964a) Keeping bugs at bay. Pig Farming 12(5):69

Pig Farming (1964b) The scourge of VPP. Pig Farming 12(6):53

Pig Farming (1965a) Disperse if you're pig. Pig Farming 13(6):51-52

Pig Farming (1965b) Camborough's progress. Pig Farming 13(12):43

Reporter (1963) If your piglets sneeze...watch out. Pig Farming 11(1):59

Price WT, Ling AW (1935-1936) Pig husbandry: an investigation conducted in the South West of England. TNA MAF 33/71.

Rae R (1934-5) Piggeries at the agricultural research institute for Northern Ireland. J Ministry Agric 41:237

Sainsbury D (1957) Comfort before cost. Pig Farming 11(5):44

Sainsbury D (1963) Pig housing. Farming Press, Ipswich

Sainsbury D (1965) Modern trends: modern management. Br Vet J 121:387-91

Saraiva T (2016) Fascist pigs: technoscientific organisms and the history of fascism. MIT Press, Cambridge

Sayer K (2013) Animal machines: the public response to intensification in Great Britain, c1960-c1973. Agric Hist 87(4):473-501

Shanks PL (1942) The housing of pigs. Veterinary Record 54:233-35

Shaw EB (1938) Swine industry of Denmark. Econ Geography 14:23-37

Shope RE (1931) Swine influenza: III Filtration experiments and etiology. J Exp Med 54(3):373-85

Smith-Howard K (2010) Antibiotics and agricultural change: purifying milk and protecting health in the postwar era. Agric Hist 85:327-51

Smith-Howard K (2017) Healing animals in an antibiotic age: veterinary drugs and the professionalism crisis 1945-1970. Technol Cult 58(3):722-48

Soutar DS (1953) Pig housing in relation to health and economy. Vet Record 65:722-40

Special correspondent (1937) Pigs on factory lines. Farmer and Stockbreeder 30 March, p. 789

Stewart W (1933) Litter losses can be reduced. Farmer and Stockbreeder 30 March, p. 661

Swann H (1963) The future of the veterinary profession: agricultural veterinary practice. Br Vet J 119:230-6

Swann MM, Baxter KL, Field HI et al. (1969) Report of the joint committee on the use of antibiotics in animal husbandry and veterinary medicine. HMSO, London

Technical Committee of Enquiry into the Welfare of Animals Kept Under Intensive Livestock Husbandry Systems (1965) Report. HMSO, London

Various (1954) BVA congress papers. Vet Record 66:862-78

Verdon N (2010) 'The modern countrywoman': farm women, domesticity and social change in interwar Britain. History Workshop Journal 70:86-107

Vernon J (2007) Hunger: a modern history. Harvard University Press, London

Vernon K (1997) Science for the farmer? Agricultural research in England 1909-36. Twentieth Century Br Hist 8:310-33
Veterinary Consultant (1963) We must control our MD herds. Pig Farming 11 (5):49-51

Veterinary Record (1958) Association for the advancement of VP-free pigs. Veterinary Record 70:322-23

Whetham E (1981) Agricultural economists in Britain, 1900-56. Institute of Agricultural Economics, University of Oxford, Oxford

White M (2018) Pig Health-Enzootic Pneumonia. Nadis bulletin. http://www. nadis.org.uk/bulletins/enzootic-pneumonia.aspx. Accessed 8 Sept 2018

Whittlestone P (1957) Some respiratory diseases of pigs. Veterinary Record 69:1354-66

Whittlestone P, Betts AO (1955) The eradication of virus pneumonia of pigs from a commercial herd. Veterinary Record 68:692-93

WHO (2015) Antimicrobial resistance: global antimicrobial resistance surveillance system: manual for early implementation. http://www.who.int/antimicrobialresistance/publications/surveillance-system-manual/en/. Accessed 8 Sept, 2018

Williams Smith H (1958) Drug-resistant bacteria in domestic animals. Proc R Soc Med 51(10):810-12

Wilsdon AJ (1958) Swine fever. Veterinary Record 70:3-12

Winnifrith J (1966). Internal correspondence: government decisions on the report, 14 Jul. TNA MAF $369 / 73$

Woods A (2012) Rethinking the history of modern agriculture: pig production in mid-20th century Britain. Twentieth Century Br Hist 23:165-91

Woods A (2013) Is prevention better than cure? The rise and fall of veterinary preventive medicine, c1950-80. Soc Hist Med 26:113-31

Woods A (2014) Science, disease and dairy production in Britain, c1927-80. Agric Hist Rev 62:294-314

Woolhouse M, Ward M, van Bunnik B, Farrar J (2015) Antimicrobial resistance in humans, livestock and the wider environment. Phil Trans R Soc B 370 (1670):20140083. https://doi.org/10.1098/rstb.2014.0083

Wye College of Agriculture (1935) Progress report. TNA MAF 33/384

Wye College of Agriculture (1938) Progress report and programme. TNA MAF 33/ 384

\section{Acknowledgements}

Research for this paper was originally undertaken as part of a fellowship funded under the UK Research Councils' Rural Economy and Land Use (Relu) Programme (RES-229 27-0001). Relu was funded jointly by the Economic and Social Research Council, the Biotechnology and Biological Sciences Research Council and the Natural Environment Research Council, with additional funding from the Department for Environment, Food and Rural Affairs and the Scottish Government. The author would like to thank these bodies, and the many scholars who have listened to different versions of this paper, for their support and advice.

\section{Additional information}

Competing interests: The author declares no competing interests.

Reprints and permission information is available online at http://www.nature.com/ reprints

Publisher's note: Springer Nature remains neutral with regard to jurisdictional claims in published maps and institutional affiliations.

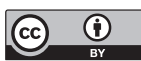

Open Access This article is licensed under a Creative Commons Attribution 4.0 International License, which permits use, sharing, adaptation, distribution and reproduction in any medium or format, as long as you give appropriate credit to the original author(s) and the source, provide a link to the Creative Commons license, and indicate if changes were made. The images or other third party material in this article are included in the article's Creative Commons license, unles indicated otherwise in a credit line to the material. If material is not included in the article's Creative Commons license and your intended use is not permitted by statutory regulation or exceeds the permitted use, you will need to obtain permission directly from the copyright holder. To view a copy of this license, visit http://creativecommons.org/ licenses/by/4.0/.

(c) The Author(s) 2019 